\title{
Role Model for Student's as Health Literacy Agent Covid 19 Vaccine
}

\author{
Anam Miftakhul Huda ${ }^{1, *}$ Tsuroyya $^{2}$ Awang Dharmawan ${ }^{3}$ Faadihilah Alodia Orlin ${ }^{4}$ \\ 1,2,3,4 Universitas Negeri Surabaya \\ *Corresponding author. Email: anamhuda@unesa.ac.id
}

\begin{abstract}
The purpose of the study was to find out the actions taken by students as agents of change in health literacy behavior to invite public to take part in the Covid-19 vaccination. The method used in this study was to use a qualitative approach by digging up information data from students who are members of the behavioral change ambassadors at the Universitas Negeri Surabaya who joined in telegeram group "Ambassadors of UNESA Behavior Change Movement Phase 2". Data collection was carried out using a google form with open research questions. The results of this study are students who are members of the behavior change ambassadors of Universitas Negeri Surabaya actively invite relatives, and the public to vaccinate in various ways, namely: 1) Students actively inform and provide explanations to the public regarding Covid-19 vaccination. The continuous provision of information carried out by these students is automatically able to increase public understanding about the importance of vaccinating Covid-19.2) Students provide education to the public by providing valid information about the Covid-19 pandemic and Covid-19 vaccination through social media. Before providing education through social media, students must seek information first through government-sponsored portals or follow a checklist created by health professionals or educators. 3) Students provide information about the place and schedule for mass vaccination activities and students also help register people who want to carry out vaccinations in that place. The recommendation that researchers give that the students will be assisted by the local government to be more active in socializing the importance of vaccines for the community in the future so they can change the mindset and behavior of people who are still afraid and hesitant to vaccinate.
\end{abstract}

Keywords: Behavior change, Covid-19 vaccine, Health literacy, Students

\section{INTRODUCTION}

The corona virus has become a world health problem, it is very important to get attention, both from scientists and the general public. The Covid-19 pandemic in Indonesia began to become a concern for both the Government and the public in March 2020 [1]. Since then the Government has started to tackle the spread of the Covid-19 virus in accordance with the directives of the WHO (World Health Organization), namely by implementing physical distancing [2] Then the State of Indonesia implemented the PSBB rules as an effort to prevent the spread of the Covid-19 virus, this caused different reactions from the public. The government began to implement a new policy known as the new normal. With this different policy, people can return to their activities while still complying with health protocols, but also these rules cause a response among the community because they are considered to increase the spread of the Covd-19 virus [3]
The spread of the Covid-19 pandemic causes various kinds of impacts, ranging from the impact of the economy, education, to the impact on global health [4]. In the midst of this conditions resulted in many changes in the social behavior of the community. For example, the polarization of people's social behavior at the time of the enactment of the PSBB which changed the issue when the government implemented a new policy, namely the new normal policy. This policy raises the same polarization of social behavior, namely the community is divided into 2 groups. Some people agree with the implementation of this new normal policy because they can return to activities such as trading, then employees are also allowed to start working in the office by implementing the health protocol [5]. However, there are also many people who do not agree with the implementation of this policy because it is considered to increase the potential for the spread of the Covid-19 virus.

This situation continues until it is informed about the Covid-19 vaccine that has been found and will be mass- 
produced to prevent the spread and transmission of the Covid-19 virus [6]. Many countries are queuing up to get the Covid-19 vaccine so that it can be given free of charge to the public, including Indonesia. It is undeniable that the Covid-19 vaccination event will certainly cause different responses among the public. In Sukmani's research (2021) it was found that $16 \%$ of Indonesians refused to vaccinate and $66 \%$ were willing to be vaccinated, this was revealed by Erick Thohir as Minister of BUMN and Chairman of the Covid-19 Handling Committee. This phenomenon shows that health literacy in Indonesia is still low.

Health literacy is all knowledge related to the health sector, especially fields related to a healthy lifestyle. In research conducted by Ratzan and Parker (2000) The Institute of Medicine defines health literacy as the ability of a person to obtain, process, and understand information and health services needed in an effort to make appropriate health-related decisions.

This kind of social behavior is certainly not formed automatically, but it is formed based on experiences that have been experienced. This experience can arise from interactions that have been carried out by the individual, this interaction can be used as learning to observe the behavior and knowledge of others. Therefore, it can be concluded that from observing the behavior and knowledge of other people, humans can learn. This knowledge and behavior is then processed with the knowledge possessed to be able to produce new knowledge and behaviors that are useful for interacting [7].

Based on this description, the formulation of the problem in this study is 1) How are the actions taken by students as health literacy agents to invite people to take part in the Covid-19 vaccination? 2) How do students act as health literacy agents if there are people who do not want to vaccinate against Covid-19? Then the purpose of holding this research is 1) To find out the actions taken by students as health literacy agents to invite the public to take part in the Covid-19 vaccination. 2) To find out the actions of students as health literacy agents if there are people who do not want to vaccinate Covid-19.

\section{METHODS}

This study uses a qualitative approach with a descriptive type. In this descriptive study, it briefly describes the conditions, the research object situations that arise in the community [8]. And it does not intend to compare or look for relationships between variables [9]. The data search method is through students who are members of the behavioral change ambassador telegram group at Universitas Negeri Surabaya stage 2. Data collection is carried out using a google form with open research questions from the number of group members 2852 and 289 students who fill out the google form. From the results of the informants, the researchers did the coding to the interpretation of the data and conclusions could be drawn.

\section{RESULTS AND DISCUSSION}

As citizens who know the importance of cutting the chain of the spread of Covid-19 virus, they must comply with the regulations and appeals that have been determined by the government so the Covid-19 virus is quickly handled so no more people are affected by the Covid-19 virus [10]. Since the Covid-19 vaccine arrived in Indonesia, not a few people have shown disapproval of the Covid-19 vaccination. In fact, the provision of this vaccine is very important, not only to protect the community from Covid-19 but also to restore the social and economic conditions of the countries affected by the pandemic.

The main purpose of the Covid-19 vaccination is to reduce the transmission of Covid-19 and reduce morbidity and mortality due to the spread of Covid-19. Achieve immunity in the community (herd immunity) and protect the community from Covid-19 in order to remain socially and economically productive. Herd Immunity or group immunity will be formed when most of the people have been vaccinated. High vaccination coverage requires the participation and cooperation of various parties to be able to overcome public reluctance and doubts about vaccination, and increase acceptance by ensuring access to accurate information about Covid19 vaccinations.

Based on the results of a survey conducted by the Ministry of Health together with ITAGI (Indonesian Technical Advisory Group on Immunization) regarding vaccine acceptance, it is known that with the support of UNICEF and WHO in September 2020, it was shown that most of the people (74\%) already knew about the government's plan to carry out the Covid vaccination. As many as $65 \%$ of the people are willing to vaccinate, as much as $27 \%$ are still hesitant to vaccinate, and about $8 \%$ said they refused to vaccinate on the grounds of worrying about the safety, effectiveness and halalness of the vaccine. Then it was also known that those who have information about Covid-19 vaccinations are more likely to receive vaccinations. Therefore, it is important to ensure that all people have access to accurate information about the handling of Covid-19, including about the Covid-19 vaccination.

Students as agents of change play an active role in helping to disseminate valid information related to vaccination. The same is true for students at Universitas Negeri Surabaya who are members of the behavioral change ambassadors. Based on the results of the questionnaires that have been collected by researchers through google forms which are then analyzed, the results obtained are students who are members of the behavior change ambassadors of Universitas Negeri Surabaya actively invite relatives, and the community to vaccinate in various ways. One of them is by providing information about the importance of vaccination to break the chain of transmission of Covid-19. Starting from 
giving the public an understanding of the Covid-19 vaccine first, then providing information from the internet and inviting them to register online.

Then the students also explained about the benefits of vaccination, which can affect the body's immunity, but it is also necessary to pay attention if you want the vaccine to be in a healthy condition. In addition to this, the students also explained that now there are many free vaccines that have been provided by the government for the community, they even provide information when there are vaccine batches available in several places.

\subsection{Students Understand and Explain the Existence of the Covid-19 Vaccine}

According to Lanning [11] information literacy is the ability to recognize when you need information, then seek, evaluate, manage, and use information efficiently, effectively, and ethically to meet the need for information while remaining an independent individual to information. In line with this, it is known that information literacy is important to be understood by every element of society so as not to misunderstand the meaning of information. Therefore, Universitas Negeri Surabaya's student who are members of the behavioral change ambassadors actively inform and provide explanations to the public regarding the Covid-19 vaccination. The continuous provision of information carried out by these students is automatically able to increase public understanding about the importance of vaccinating Covid-19.

\subsection{Students Educate Through Social Media the Importance of the Covid-19 Vaccination}

Health literacy carried out with the aim of educating people about severe acute respiratory syndrome coronavirus 2 (SARS-CoV-2) and how to avoid or spread infection has become widely available. Most of the information is created in an easy-to- understand way that offers simple and practical solutions, such as washing hands, physical distancing, and seeking information on the latest recommendations. Unfortunately, there is also complex, contradictory, and false information.

As an effort to increase awareness about health literacy in the midst of a pandemic, students provide education to the public by providing valid information about the Covid-19 pandemic and Covid-19 vaccination through social media. Before providing education through social media, students first look for information through portals sponsored by the government or follow a checklist created by health professionals or educators. Currently, the CDC and WHO have created public access in the form of a database on the corona virus, so that they can provide reliable information from the newest sources [12]
Education through digital media is considered more effective and efficient because the use of digital information, especially the Internet, can improve or activate health and health services. Norman \& Skinner [13], defines health literacy in a digital society as "the ability to search, find, understand, and assess health information from electronic sources and apply the acquired knowledge to address or solve health problems".

\subsection{Students Give Examples to the Community for Vaccines}

Currently, health posters with the theme of preventing the spread of the Covid-19 virus can be found easily in all places. In various media, both print and digital, information is often found regarding the curve of the spread of Covid-19, causing an effect of anxiety among the public. The rapid flow of information makes it easier for every individual to access various information in the media, whether it is accurate information or just hoax news. Therefore, health literacy is important to be mastered by the community. Health literacy can encourage people to have the ability to sort and determine which health information should be received and can be used as guidelines in daily behavior.

According to Harlock in Apriliani \& Utami's [14] research, it is explained that there are 3 levels of health literacy in empowerment including, 1) basic level which is the basic ability to read and understand care instructions; 2) middle level, that is, someone has the ability to relate prior knowledge to information in the environment; and 3) high level, namely a person's ability to assess an information received and then conveyed back to others as the development of information in the health sector.

The solution that can be used to improve health literacy among the community is to involve the community directly in efforts to improve joint health. Currently, efforts to actively involve community members in increasing awareness about health have begun to be carried out. One of them is an activity carried out by students of Universitas Negeri Suarabaya. The activities carried out are in the form of providing information about the place and schedule of mass vaccination activities. In addition, students also do not hesitate to help register people who want to carry out vaccinations in that place. This is done in order to increase public awareness and vigilance during the Covid-19 pandemic. This refers to the high-level theory in health literacy levels conveyed by Harlock, where students who are members of behavioral change ambassadors provide examples or experience education when vaccinating Covid-19 and actively invite people to do the same. 


\section{CONCLUSION}

Based on the presentation of the results and discussion of the research above, it can be concluded that students who are members of the behavior change ambassadors of Universitas Negeri Surabaya actively invite relatives and the public to vaccinate in various ways, namely: 1) Students actively inform and provide explanations to the public regarding Covid vaccination 19. The continuous provision of information carried out by these students is automatically able to increase public understanding about the importance of vaccinating Covid-19. 2) Students provide education to the public by providing valid information about the Covid-19 pandemic and Covid-19 vaccination through social media. Before providing education through social media, students must seek information through government-sponsored portals first or follow a checklist created by health professionals or educators. 3) Students provide information about the place and schedule for mass vaccination activities and students also help register people who want to carry out vaccinations in that place. It is done in order to increase public awareness and vigilance during the Covid-19 pandemic. In the future, students should be assisted by the local government to be more active and aggressive in socializing the importance of vaccines for the community so they can change the mindset and behavior of people who are still afraid and hesitant to vaccinate.

\section{ACKNOWLEDGMENT}

We would like to express our gratitude to the PNBP of the Faculty of Social Sciences and Law, Universitas Negeri Surabaya, which has funded this research. We would also like to thank all parties who were actively involved in the research.

\section{REFERENCES}

[1] Ihsanuddin, "Fakta Lengkap Kasus Pertama Virus Corona di Indonesia," 2020. [Online]. Available: https://nasional.kompas.com/read/2020/03/03/063 14981/fakta-lengkap-kasus-pertama-virus-coronadi-indonesia?page $=$ all.

[2] D. P. K. Kartanegara, "Penerapan Jaga Jarak Fisik Physical Distancing Dalam Pencegahan Covid 19 Corona Virus," 2020. [Online]. Available: https://dishub.kukarkab.go.id/pages/penerapanjaga-jarak-fisik-physical-distancing-dalampencegahan-covid-19-corona-virus.

[3] Anonymous, "Mengenal Konsep New Normal," 2020. [Online]. Available: Indonesia.go.id - .

[4] R. Fauziah and K. Dian Pertiwi, "Hubungan Literasi Kesehatan Terhadap Perilaku Pencegahan Covid-19 Pada Masyarakat Di Desa Sarwodadi Kecamatan Comal Kabupaten Pemalang,"
Universitas Ngudi Waluyo, 2021.

[5] Advetorial, "Menyelamatkan Ekonomi Indonesia Melalui Penerapan New Normal," 2020. [Online]. Available:

https://www.cnnindonesia.com/ekonomi/2020061 6191535-297-514013/menyelamatkan-ekonomiindonesia-melalui-penerapan-new-normal.

[6] R. Franedya, "Kabar Terbaru Perlombaan Penemuan Vaksin Corona Versi WHO," 2020. [Online]. Available: https://www.cnbcindonesia.com/tech/2020120713 5651-37-207365/kabar-terbaru-perlombaanpenemuan-vaksin-corona-versi-who.

[7] K. N. A. Sukmani, "Lifeworld fotografer human interest: berkarya di media sosial instagram," Universitas Indonesia, Depok, 2018.

[8] R. Juwandi, "Efektivitas Reformasi Birokrasi Dalam Konteks Kecakapan Warga Negara (Civic Skill) Sebagai Upaya Mewujudkan Good Governance," Universitas Pendidikan Indonesia, Bandung, 2015.

[9] D. Sopian and W. Suwartika, "Pengaruh Sistem Informasi Akuntansi Dan Sistem Pengendalian Internal Terhadap Kinerja Karyawan," Jurnal Sains Manajemen dan Akuntansi, vol. 11, no. 2, pp. 40-53, 2019.

[10] S. R. A and e. al, "Menumbuhkan Kesadaran Masyarakat Indonesia Untuk Memutus Rantai Penyebaran Wabah Covid-19," Jurnal Globai Citizen: Jurnal Ilmiah Kajian Pendidikan Kewarganegaraan, vol. 9, no. 1, pp. 51-62, 2020.

[11] S. Lanning and J. Mallek, "Factors Influencing Information Literacy Competency of College Students," The Journal of Academic Librarianship, vol. 43, no. 5, pp. 443-450, 2017.

[12] M. F. Syah, R. A. J. Winarno and D. G. Ahya, "Literasi Kesehatan dalam Penanggulangan Pandemik COVID-19," Jurnal AKRAB, vol. XI, no. 1, pp. 70-76, 2020.

[13] C. D. Norman and H. A. Skinner, "eHEALS: The eHealth Literacy Scale," Journal of Medical Internet Research, vol. 8, no. 4, pp. 1-7, 2006.

[14] S. R. A. Apriliani and F. B. Utami, "Peran Orang Tua dalam Menerapkan Kemampuan Literasi Kesehatan Anak Usia Dini pada Pandemi Covid-19 Dilingkungan Rt 0426 Pekayon Jaya, Bekasi Selatan," Jurnal Pendidikan Tambusai, vol. 5, no. 2, pp. 3852-3862, 2021. 